\title{
editorial
}

\section{The French Fact}

While working in Northern Quebec last summer the writer found himself in the absurb position of having to attempt to explain some research work twice to two recent graduates of Canadian forestry schools: once in French and once in English. The forestry schools at Quebec and Fredericton are only a few hundred miles apart, and in the same country, and yet those two young foresters could not even communicate with each other.

With the bulk of the woods labour in Eastern Canada being French speaking and most of the senior administration of the forest industries being English speaking, and with an increasing trend to bilingualism in the secondary forest industries and in the federal civil service, the monolingual forestry graduate is ill-prepared to face the realities of the forestry profession outside of the ranks of the provincial Departments of
Lands and Forests.

Most graduates of the Laval forestry school rarely venture outside the province for employment, probably because of cultural and lan. guage problems. Young English speaking foresters hired by industry in Quebec have traditionally been placed in the woods to get experience and learn French. It is hardly surprising some come out speaking "joual"!

There could be benefits not only for Canada and individual foresters, but also for the Canadian Institute of Forestry and the Provincial Professional Forestry groups in Ontario, Quebec and New Brunswick, if all graduate foresters had a working knowledge of both languages. Two ways to achieve this would be: to initiate one year student exchange programs between Laval and the other forestry schools, and to increase inter-provincia! summer employment opportunities.

G. F. Weetman
Editor

G. F. Weetman 570 St. John's Rd. Pointe Claire, P.Q.

\section{Associate Editors}

Fire D. E. Williams

Forest Economics \& Policy D. V. Love

Forest Entomology I. W. Varty

Forest Pathology G. Wallis

Forest Products R. H.J. Creighton Forest Monogement G. F. Weetman

Logging H. I. Winer

Silviculture

R. J. Day

D. Glew

W:ildlife

D. H. Pimlott

French Associate Editor H. LeBlonc

Published bi-monthly by the Canadian Institute of Forestry - Institut Forestier du Canada. Address all correspondence concerning business motters to A. G. Racey, Secretary-manager, P.O. Box 5000, Macdonald College, P.Q., Canada. Subscription rates $\$ 8.00$ per year. $\$ 2.00$ single copies. Authorized as second class mail, Post Office Department, Ottowa and for payment of postage in cash. Return postage guaranteed.

The Institute ossumes no responsibility for the statements and opinions expressed by contributors. Authors, or their supporting agencies are required to pay two-thirds of the publication cost for articles longer than 8 pages.

담ㅁ 